\title{
Antipsychotic effects of Philenoptera cyanescens (Schum. \& Thonn.) Roberty (Leguminosae) Leaf Extract and Fractions against Ketamine-induced Psychosis in Mice
}

\author{
Mubo Adeola Sonibare ${ }^{*}$, Isimot Temitope Arowona ${ }^{1,2}$, Khalid Rauf ${ }^{2}$ \\ 1 Department of Pharmacognosy, Faculty of Pharmacy, University of Ibadan, Ibadan, Nigeria \\ 2 NeuroPharmacology Unit, Department of Pharmacy, COMSATS Institute of Information Technology, Abbottabad, Pakistan
}

\begin{abstract}
This study investigated the antipsychotic potentials of Philenoptera cyanescens (PC) methanol extract and fractions against ketamine-induced psychosis in Balb/C mice.

The methods used were the hyper-locomotion, stereotype behaviour, Y-maze and Forced Swim Test models. The extrapyramidal effect of the active fractions was tested using the catalepsy model.

The crude extract and all fractions at varying doses significantly reduced ketamineinduced hyperactivity and stereotype behaviour with dichloromethane fraction being the most active compared with the standards. Dichloromethane and ethyl acetate fractions $(250 \mathrm{mg} / \mathrm{kg})$ reversed the cognitive impairments enhanced by ketamine at the $1^{\text {st }}, 5^{\text {th }}$, and $10^{\text {th }}$ day of the experiments and also decreased the immobility time in the FST model at $11^{\text {th }}$ and $15^{\text {th }}$ days post treatment. The two fractions did not induce catalepsy and also inhibited the cataleptic effect induced by haloperidol.

The results established that Philenoptera cyanescens possesses antipsychotic effect against positive, negative and cognitive symptoms of psychosis.
\end{abstract}

Keywords: Philenoptera cyanescens, Antipsychotic activity, Hyper-locomotion, Stereotypy, Forced swim test

\section{INTRODUCTION}

Psychosis is a mental health problem involving loss of contact with reality. It affects as many as 450 million people worldwide, about a million people en-

\footnotetext{
*Corresponding Email: Mubo Adeola Sonibare, e-mail: sonibaredeola@yahoo.com Mubo Adeola Sonibare ORCID Number: 0000-0003-1252-6758

Isimot Temitope Arowona ORCID Number: 0000-0003-4561-9125

Khalid Rauf ORCID Number: 0000-0003-3967-9623

(Received 17 September 2019, accepted 28 November 2019)
} 
danger their lives by committing suicide every year and one out of four families has one member with mental disorder ${ }^{1}$. Its symptoms include schizophrenia, hallucination, social withdrawal, incoherent behaviour/speech, difficulty in concentration, anxiety, depressed mood, and suicidal thoughts. Despite the burden of this illness to the society, the treatment is still poor among patients, hence, patients especially from less developed countries like Nigeria prefer to seek treatment from traditional healers. They believe traditional medicine is safer, less expensive and easily assessable than orthodox antipsychotic drugs such as haloperidol, chlopromazine (typical antipsychotics), risperidone and clozapine (atypical antipsychotics). The long-term use of these drugs results into extra pyramidal effects, high oxidative damage ${ }^{2}$, and this could result in agranulocytosis, cardiovascular disorders, diabetes and some other severe conditions ${ }^{3-5}$.

The models (Hyper-locomotion, stereotypy, Y-maze test, Forced Swim test and catalepsy) used in this study have been reported to mimic psychosis in human. Locomotion is mostly increased by central nervous system (CNS) stimulants and reduced by CNS depressants ${ }^{6}$. Enhanced locomotory activity has been linked to the dopaminergic hyper activation in striatal areas of mouse brain ${ }^{7}$ Stereotypy mostly seen in people with mental disorder is usually in the form of repetitive performance of a set of strange behaviours such as making the same kind of comments or asking the same questions ${ }^{\mathbf{8}, 9}$. In experimental animals, it is usually observed as persistent sniffing, abnormal sideways movements of the head, intense licking, and chewing behaviours ${ }^{10}$. Cognitive dysfunction such as attention deficits, short- and long-term working memory are symptoms seen in psychotic patients ${ }^{11}$. The Y-maze test has previously been used to investigate the effectiveness of antipsychotic drugs on memory and learning function in rodents $^{12}$. It involves measuring the spatial working memory, which is based on rodent's willingness to explore new environments. Rodents prefer to explore new arm of the maze, rather than return to a previously visited arm. In addition, chronic administration of ketamine has been reported to enhance immobility in forced swim test and used as a model for negative symptoms of psychosis ${ }^{13}$ such as avolition (severe decrease in motivation to initiate and perform self-directed purposeful tasks). Catalepsy has been used to predict safe tranquillizing activity and also to access motor effects of drugs, especially effects related to extrapyramidal symptoms (EPS) ${ }^{14}$. It is one of the major side effects related to the use of orthodox antipsychotic drugs ${ }^{15}$. The EPS has been linked to the decrease of striatal dopamine D1 and D2 receptors ${ }^{16,17}$. The great burden of the various side effects associated with the use of antipsychotics has therefore led to a continuous search for novel and well tolerated molecules 
from natural resources to control severe mental disorders ${ }^{18-22}$.

High chemical diversity, biochemical specificity, and several other medicinal properties such as anti-inflammatory, anti-psychotic, antioxidant properties among others are characteristics of natural products, which enable them to possess favourable lead structures for the treatment of various disorders, including psychosis. Some plants like Hypericum perforatum L. (Saint John's Wort) ${ }^{23-27}$, Psidium guajava L. ${ }^{28}$, Newbouldia laevis Seem. ${ }^{29}$, Bacopa monniera $^{30-32}$, Synedrella nodiflor ${ }^{33}$ and many others have been screened for their neuroleptic activities. In line with this, Lonchocarpus cyanescens (Schumach and Thonn.) Benth. now called Philenoptera cyanescens (PC) (Schum. \& Thonn.) Roberty, is a medicinal plant used traditionally in south western $\mathrm{Ni}$ geria to treat mental disordered patients ${ }^{42}$, and we have reported the antipsychotic properties of this plant in amphetamine and apomorphine-induced psychotic models ${ }^{34,35}$. Both amphetamine and apomorphine used in the study to induce psychosis work by blocking the $\mathrm{D}_{2}$ receptor (positive symptoms only). In this study, the antipsychotic potential of the crude extract and fractions of $P$. cyanescens was investigated on ketamine-induced psychosis in mice. Ketamine is known to affect positive, negative and cognitive functions of the brain ${ }^{36}$ alongside the extrapyramidal side effects usually found in orthodox antipsychotics. Since PC possesses antipsychotic properties against apomorphine and amphetamine induced psychosis, our hypothesis is that it may be effective against ketamine models of psychosis. Thus, the present study investigates the effect of the extract and fractions of $P$. cyanescens against positive, negative and cognitive symptoms in ketamine-induced experimental psychosis in mice.

\section{METHODOLOGY}

\section{Preparation of crude extract and fractions}

Philenoptera cyanescens leaves were collected at Kajola, Ibadan, Oyo State, Nigeria and identified at the Forest Herbarium Ibadan (FHI) by Dr. O. A. Osiyemi of the Forest Research Institute of Nigeria where specimen was deposited with voucher number FHI 109689. Shade-dried whole plant (3 kg) was pulverized and macerated using methanol for $72 \mathrm{~h}$. The methanol extract was filtered and concentrated in vacuo at $40^{\circ} \mathrm{C}$. The residue was re-extracted twice for optimum yield of the extract. The crude extract was dissolved in methanol: water (1:1) and partitioned into HEX, DCM, EtOAc, BuOH and aqueous (Aq) fractions. The crude extract and fractions of $\mathrm{PC}$ were stored in the refrigerator until ready for use. 


\section{Experimental Animals}

Balb C albino mice of both sex between 7 - 9 weeks old (30-35 g) used for the study were purchased from National Institute of Health (NIH), Islamabad, Pakistan. They were housed ten to twelve per cage (L X B X H: $16 \mathrm{~cm} \mathrm{x} 10 \mathrm{~cm}$ x $6 \mathrm{~cm}$ ) at room temperature, and $12 \mathrm{~h}$ to $12 \mathrm{~h}$ light-dark cycle (8:00 a.m-8:00 p.m.). The cages were lined with soft wood shavings, used as beddings to absorb waste products from the animals, and changed after 3 days. They were allowed to acclimatize for minimum of one week before the start of experimental procedures. The animals were also acclimatized to each of the experimental procedures after which they were randomly distributed into different treatment groups ( $\mathrm{n}=6$ per group, in ratio 1:1 of both male and female animal) of both sex. There were eighteen experimental groups and three control groups for the acute study, as shown in Table 1 . They had free access to constant food pellets and water ad libitum. The experiments were performed after approval of the protocol by the Ethics Committee of the COMSATS Institution of Information Technology, Abbottabad, Pakistan, according to the National Institutes of Health Guide for care and use of laboratory animals.

\section{Drugs and Treatments}

Ketamine was purchased from Indus Pharma, Karachi, Pakistan, haloperidol (injection) from The Searle Company Limited, Karachi, Pakistan and risperidone (risperidal tablet) from West-Coast Pharmaceutical, India. Haloperidol and risperidone $(0.2 \mathrm{mg} / \mathrm{kg})$ were used so as to compare the effect of the plant extract and fractions with typical and atypical antipsychotics, respectively. All drugs (plant extracts) were administered orally at a dose of 125, 250 and 500 $\mathrm{mg} / \mathrm{kg}$; these doses were used based on the results obtained from preliminary studies. Experiments were carried out in the laboratory, between the hours of 8 a.m. - 4 p.m., using different observation chambers as required by each model. 
Table 1. Animal Grouping

\begin{tabular}{|l|l|}
\hline Group & Treatment \\
\hline 1 & Ketamine $(30 \mathrm{mg} / \mathrm{kg})+$ Distilled water $(10 \mathrm{~mL} / \mathrm{kg})$ \\
\hline 2 & Ketamine $(30 \mathrm{mg} / \mathrm{kg})+$ Haloperidol $(0.2 \mathrm{mg} / \mathrm{kg})$ \\
\hline 3 & Ketamine $(30 \mathrm{mg} / \mathrm{kg})+$ Risperidone $(0.2 \mathrm{mg} / \mathrm{kg})$ \\
\hline $4,5,6$ & Ketamine $(30 \mathrm{mg} / \mathrm{kg})+$ PC crude extract $(125,250,500 \mathrm{mg} / \mathrm{kg})$ \\
\hline $7,8,9$ & Ketamine $(30 \mathrm{mg} / \mathrm{kg})+$ PC Hexane $(125,250,500 \mathrm{mg} / \mathrm{kg})$ \\
\hline $10,11,12$ & Ketamine $(30 \mathrm{mg} / \mathrm{kg})+$ PC Dichloromethane $(125,250,500 \mathrm{mg} / \mathrm{kg})$ \\
\hline $13,14,15$ & Ketamine $(30 \mathrm{mg} / \mathrm{kg})+$ PC Ethyl acetate $(125,250,500 \mathrm{mg} / \mathrm{kg})$ \\
\hline $16,17,18$ & Ketamine $(30 \mathrm{mg} / \mathrm{kg})+$ PC Butanol $(125,250,500 \mathrm{mg} / \mathrm{kg})$ \\
\hline $19,20,21$ & Ketamine $(30 \mathrm{mg} / \mathrm{kg})+$ PC Aqueous $(125,250,500 \mathrm{mg} / \mathrm{kg})$ \\
\hline
\end{tabular}

\section{Behavioural Assays}

Hyper-locomotion and stereotypy were performed based on previously described methods ${ }^{35}$, ${ }^{36}$, Forced Swim test and Y-maze test were performed according to described methods ${ }^{36,14}$.

\section{Hyper-locomotion in mice}

The open field test model was employed to observe hyper-locomotion in animals. The total number of animals used (126) was obtained by the formula; $\mathrm{Ta}$ $=N a \times N g$,

Where $\mathrm{Ta}$ is the total number of animals, $\mathrm{Na}$ is the number of animal per group and $\mathrm{Ng}$ is the number of groups in the study.

The chamber was made of wood with dimensions of $35 \mathrm{~cm} \times 30 \mathrm{~cm} \times 23 \mathrm{~cm}$, Here, animals ( $n=6$ per group) were administered with crude extract, HEX, DCM, EtOAc, BuOH or Aq fractions (125 - $500 \mathrm{mg} / \mathrm{kg}$ ) of PC orally $1 \mathrm{~h}$ before the injection of ketamine (30 mg/kg, i.p), thereafter; they were placed at the centre of an open field chamber $(35 \mathrm{~cm} \times 30 \mathrm{~cm} \times 23 \mathrm{~cm})$, immediately after ketamine injection. The number of lines crossed and time at which it did not move (time of ambulation) were recorded for 5 min using a mobile camera.

\section{Stereotype behaviour in mice}

The antagonistic effect of the crude extract and fractions of PC were tested on ketamine-induced stereotype behaviour using the same mice that were used for hyper-locomotion study. Animals were placed in transparent observation chamber (L X B X H: $16 \mathrm{~cm}$ x $10 \mathrm{~cm} \mathrm{x} 6 \mathrm{~cm}$ ) 5 min after ketamine injection 
immediately after the hyper-locomotion experiment. Thereafter, stereotype parameters were observed and recorded for a period of 2 min at 5, 10, 15, 20, 30, 45, and $60 \mathrm{~min}$, respectively. Stereotypy parameters were scored as $\mathrm{O}=\mathrm{ab}-$ sence of stereotypy parameters, $1=$ presence of stereotyped movements of the head, 2 = intermittent sniffing, $3=$ chewing, and $4=$ intense licking.

\section{Forced Swim Test (FST)}

The forced swim test was carried out on the bioactive fractions, PC DCM and PC EtOAc. It is a measure of behavioural despair and was carried out according to $^{36}$ with little modification. In this test, mice were treated with distilled water, haloperidol $1 \mathrm{mg} / \mathrm{kg}$, risperidone $0.2 \mathrm{mg} / \mathrm{kg}$, p.o., PC DCM (125, 250 and 500 $\mathrm{mg} / \mathrm{kg}$, p.o.), and PC EtOAc (125, 250 and $500 \mathrm{mg} / \mathrm{kg}$, p.o.), $60 \mathrm{~min}$ before administration of ketamine $30 \mathrm{mg} / \mathrm{kg}$, i.p. for 10 days. FST was then performed $24 \mathrm{~h}$ after the last treatment day. Effect of chronic treatment of the fractions and standards were also tested at day 15 after withdrawal. Briefly, mice were placed individually in the center of a transparent glass cylinder (height $-23 \mathrm{~cm}$, diameter $-40 \mathrm{~cm}$ ) which contained water at room temperature to a depth of 16 $\mathrm{cm}$ and acclimatized for $2 \mathrm{~min}$ (trial phase), $24 \mathrm{~h}$ after the trial phase, mice were again placed in the cylinder, and swimming activity was recorded for 5 min after 1 min of acclimatization. Duration of immobility was observed and recorded; mice were considered immobile when they were floating motionless in water.

\section{Y-maze Test}

The effect of the bioactive fractions of PC (DCM and EtOAc) on cognitive dysfunction by measuring the correct alternation were tested in the Y-maze paradigm in mice, according to ${ }^{14}, 19$, with little modification. Sixty mice were divided into (and treated with) control group (distilled water $10 \mathrm{~mL} / \mathrm{kg}$, p.o.), negative control group (ketamine $30 \mathrm{mg} / \mathrm{kg}$, i.p.), positive control groups (haloperidol $1 \mathrm{mg} / \mathrm{kg}$ and risperidone $0.2 \mathrm{mg} / \mathrm{kg}$, p.o.), PC DCM (125, 250 and $500 \mathrm{mg} / \mathrm{kg}$, p.o.), and PC EtOAc (125, 250 and $500 \mathrm{mg} / \mathrm{kg}$, p.o.) groups, containing six mice per group, with an hour interval between the oral and intraperitoneal administration. Treatments were given for 10 days and behavioural experiment was carried out at day 1, day 5 and day 10. Three wooden arms (Length $30 \mathrm{~cm}$ $\mathrm{x}$ Breadth $5 \mathrm{~cm}$ x Height $10 \mathrm{~cm}$ ), symmetrically separated at $120^{\circ}$ each was used for the study. On day 1 , animals were placed at the closed end of arm A, 1 hour after treatment, and allowed to explore all the three labelled arms (A, B, C) freely for $5 \mathrm{~min}$, whereas on day 5 and day 10, experiments were carried out after $24 \mathrm{~h}$ of treatment. Parameters recorded were sequence of alternation and number of arm entry. The Y-maze apparatus was cleaned with 70\% ethanol to remove residual odour after each mouse session. 
Percentage correct alternation was calculated using the formula:

Sequence of alternation / number of arm entry -2 multiplied by 100 .

\section{Catalepsy}

The cataleptic side effects of antipsychotic drugs have been routinely measured using the standard bar test ${ }^{37}$. Haloperidol (1.0 mg/kg. i.p) was used to induce catalepsy and the time (sec) the mouse maintain an imposed position with both forepaws resting on a $4 \mathrm{~cm}$ high glass horizontal bar (1.0 $\mathrm{cm}$ diameter) was recorded. Time recording was terminated when both front paws were removed from the bar or if the mouse moves its head in an exploratory way, and a cut-off time of 5 min was applied. Observations were taken at o, 30, 60, 90, and 120 min after administration of $\operatorname{drug}^{38,39}$. Group 1 received distilled water (10 mL/kg, positive control), group 2 received haloperidol ( $1 \mathrm{mg} / \mathrm{kg}$; i.p, negative control) only, groups 3 and 4 received either DCM or EtOAc fractions of PC $(125 \mathrm{mg} / \mathrm{kg}$ and $500 \mathrm{mg} / \mathrm{kg}$; p.o), groups 5 and 6 received either haloperidol (1 $\mathrm{mg} / \mathrm{kg}$; i.p) with DCM fraction or haloperidol ( $1 \mathrm{mg} / \mathrm{kg}$ ) with EtOAc fraction at lower (125 mg/kg) and higher doses (500 mg/kg), respectively. In all, 60 mice were used for the study, derived from the formula above.

\section{Statistical analysis}

One and two - way analysis of variance (ANOVA) was employed to compare all groups against the negative control group after which Dunnett's and Bonferroni post hoc test was used. Values were presented as mean \pm standard error of mean, and a p-value of $0.05,0.01$ or 0.001 was considered statistically significant.

\section{RESULTS AND DISCUSSION}

\section{Inhibition of ketamine induced hyper-locomotion by crude extract of PC}

The group of mice that received crude extract of PC showed reduction in the locomotion activity in ketamine-induced psychotic mice at $125 \mathrm{mg} / \mathrm{kg} \mathrm{b.w}$. when compared with the mice induced with ketamine only (negative control group) (Figure 1). The antagonism of hyper-locomotion at a lower dose of $125 \mathrm{mg} / \mathrm{kg}$ encouraged us to go further by fractionating the crude extract and tested the different fractions on locomotion and other models of psychosis.

All the doses of the hexane and DCM fractions of PC (125 mg/kg, 250 mg/kg, and $500 \mathrm{mg} / \mathrm{kg}$ ) significantly reduced the hyper-locomotion $\left(\mathrm{PC} \mathrm{Hex} \mathrm{F}_{3,20}=12.57\right.$, *** $\left.\mathrm{P}<0.001, \mathrm{R}^{2}=65 \%, \mathrm{PC} \mathrm{DCM} \mathrm{F} \mathrm{F}_{3,20}=13.99,{ }^{* * *} \mathrm{P}<0.001, \mathrm{R}^{2}=68 \%\right)$ induced by ketamine $(30 \mathrm{mg} / \mathrm{kg}$ ) with a comparable effect to the standards: haloperidol and risperidone $(0.2 \mathrm{mg} / \mathrm{kg})\left[\mathrm{F}_{2,15}=28.22,{ }^{* *} \mathrm{P}<0.001, \mathrm{R}^{2}=79 \%\right]$. The EtOAc 
fraction of PC also showed significant reduction at $250 \mathrm{mg} / \mathrm{kg}\left({ }^{*} \mathrm{P}<0.05\right)$, while $\mathrm{BuOH}$ fraction was significant at $250 \mathrm{mg} / \mathrm{kg}$ and $500 \mathrm{mg} / \mathrm{kg}\left({ }^{* * *} \mathrm{P}<0.001\right.$ and ${ }^{*} \mathrm{P}<0.05$, respectively). When compared with the negative control group, the aqueous fraction of PC did not show any significant reduction in locomotion.
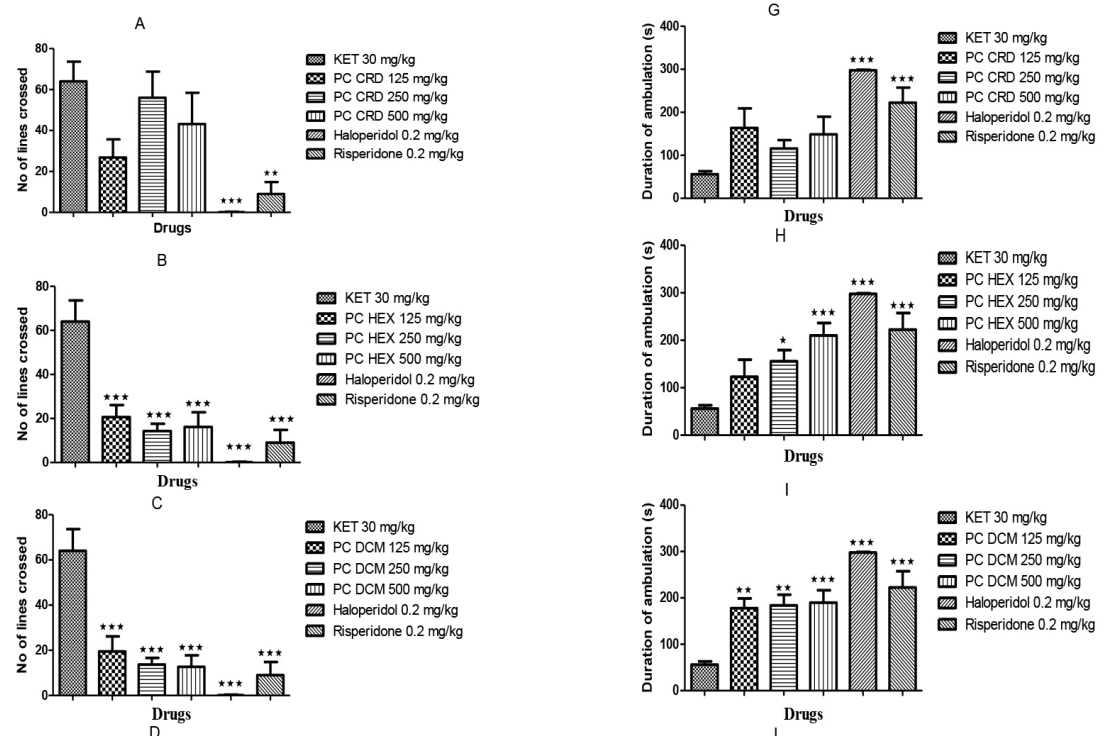

Drugs

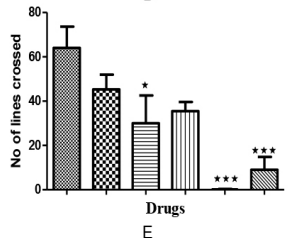

KET $30 \mathrm{mg} / \mathrm{kg}$

X0 PC EtOAc $125 \mathrm{mg} / \mathrm{kg}$

ㅁ PC EtOAc $250 \mathrm{mg} / \mathrm{kg}$

四 PC EtOAC $500 \mathrm{mg} / \mathrm{kg}$

Haloperidol $0.2 \mathrm{mg} / \mathrm{kg}$

Risperidone $0.2 \mathrm{mg} / \mathrm{kg}$
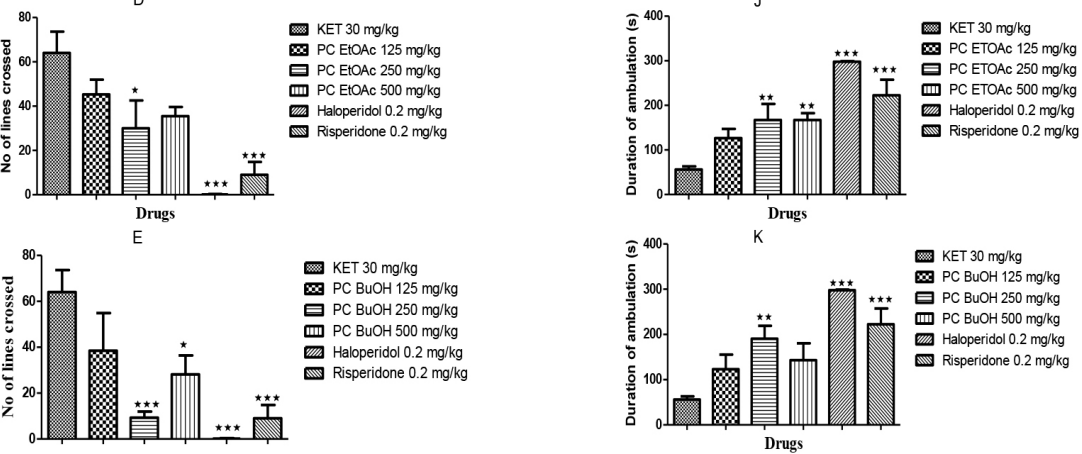

KET $30 \mathrm{mg} / \mathrm{kg}$

PC BuOH $125 \mathrm{mg} / \mathrm{kg}$

PC BuOH $250 \mathrm{mg} / \mathrm{kg}$

四 PC BuOH $500 \mathrm{mg} / \mathrm{kg}$

Haloperidol $0.2 \mathrm{mg} / \mathrm{kg}$

Risperidone $0.2 \mathrm{mg} / \mathrm{kg}$

Drugs
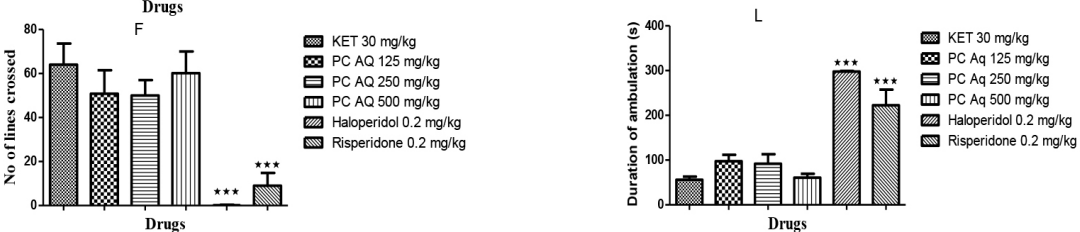

Figure 1. Number of lines crossed (A-F) and duration of ambulation (G-L) in mice administered with PC crude extract and fractions (HEX, DCM, EtOAc, BuOH and Aq, respectively; $125-500 \mathrm{mg} / \mathrm{kg}$; orally) $1 \mathrm{~h}$ before ketamine (30 mg/kg; i.p.) administration. Data's were mean \pm SEM $(n=6)$. ${ }^{*} P<0.05$, ${ }^{* *} P<0.01$, ${ }^{* *}{ }^{*} P<0.001$ compared with negative control group (one-way ANOVA followed by a Dunnett's multiple comparison post hoc test). 


\section{Antagonism of stereotype behaviour by PC crude extract and frac- tions in ketamine-induced Stereotypy}

Treatment with ketamine in mice is known to cause stereotypy. Ketamine-induced stereotype behaviour is characterized by intermittent sniffing, head movement and chewing. The group of animals treated with PC crude extract significantly reduced the stereotypy behaviour induced by ketamine at $500 \mathrm{mg} / \mathrm{kg}\left(\mathrm{F}_{3,24}=5.54\right.$, ${ }^{* *} \mathrm{P}<$ o.01), likewise haloperidol and risperidone (0.2 $\mathrm{mg} / \mathrm{kg}$ ) the standard typical and atypical antipsychotics, respectively (Figure 2a). The fractions of PC were also observed for their effect in antagonizing ketamine-induced stereotype behaviour, one way ANOVA results showed that Hex fraction was significant $\left({ }^{*} \mathrm{P}<0.05, \mathrm{~F}_{3,24}\right.$ $=3.31$ ) although not significant at Dunnett's multiple comparison test when the doses were compared each with the negative control (Figure $2 b$ ). The DCM fraction significantly $\left({ }^{* *} \mathrm{P}<0.001\right)$ antagonized stereotype behaviour in the mice and when compared with Dunnett's post hoc test, it was also significant at $250 \mathrm{mg} / \mathrm{kg}$ $\left({ }^{* *} \mathrm{P}<0.01\right)$ as shown in Figure 2c. At $500 \mathrm{mg} / \mathrm{kg}$, the EtOAc fraction significantly ( ${ }^{*} \mathrm{P}<0.05$ ) reduced stereotypy behaviour (Figure $2 \mathrm{~d}$ ). However, the $\mathrm{BuOH}$ fraction did not reduce stereotype behaviour significantly in the mice (Figure 2e), while Aq fraction at $125 \mathrm{mg} / \mathrm{kg}$ significantly ( $\left.{ }^{* *} \mathrm{P}<0.01\right)$ reduced stereotype behaviour (Figure 2f). All animals used in the study were used for analysing the result.
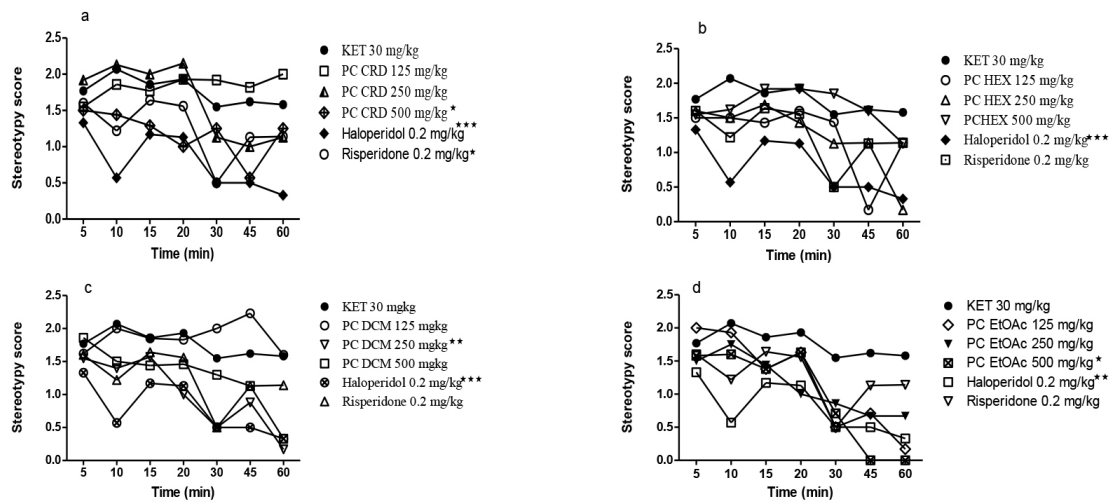

- KET $30 \mathrm{mgkg}$

PC DCM $125 \mathrm{mgkg}$

$\nabla$ PC DCM 250 mgkg

HCDCM $500 \mathrm{mgkg}$

$\triangle$ Risperidone $0.2 \mathrm{mg} / \mathrm{kg}$

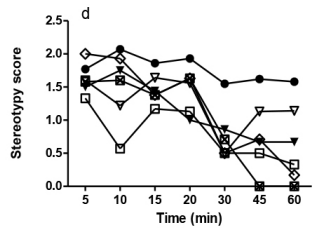

- $\mathrm{KET} 30 \mathrm{mg} / \mathrm{kg}$

PC EtOAC $125 \mathrm{mg} / \mathrm{kg}$

PC EtOAc $250 \mathrm{mg} / \mathrm{kg}$.

PC EtOAc $500 \mathrm{mg} / \mathrm{kg}^{\star}$ *

Risperidone $0.2 \mathrm{mg} / \mathrm{kg}$

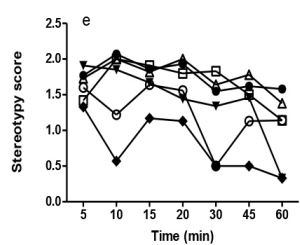

- KET $30 \mathrm{mg} / \mathrm{kg}$

口 PC BuOH $125 \mathrm{mg} / \mathrm{kg}$

$\triangle \mathrm{PC} \mathrm{BuOH} 250 \mathrm{mg} / \mathrm{kg}$

PC BuOH $500 \mathrm{mg} / \mathrm{kg}$

Raloperidol $0.2 \mathrm{mg} / \mathrm{kg}^{\star \star \star}$

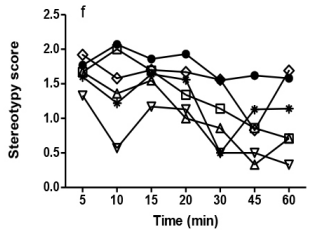

- KET $30 \mathrm{mg} / \mathrm{kg}$

$\triangle P C$ AQ $125 \mathrm{mg} / \mathrm{kg}^{\star \star}$

口 $P C A Q 250 \mathrm{mg} / \mathrm{kg}$

$\diamond P C$ AQ $500 \mathrm{mg} / \mathrm{kg}$

$\nabla$ Haloperidol $0.2 \mathrm{mg} / \mathrm{kg}^{\text {t* }}$

Figure 2. Effect of Philenoptera cyanescens crude extract-a, and fractions (b-Hex, c-DCM, d-EtOAc, e-BuOH and f-Aq; $125-500 \mathrm{mg} / \mathrm{kg}$; orally), Haloperidol, Risperidone and negative control on stereotype behaviour, $5 \mathrm{~min}$ after ketamine (30 mg/kg, i.p) treatment in a transparent 
observation chamber. Data were mean $\pm \operatorname{SEM}(n=6) .{ }^{*} P<0.05,{ }^{\star \star} P<0.01,{ }^{* \star *} P<0.001$, compared with negative control group (one-way ANOVA followed by a Dunnett's multiple comparison post hoc

\section{Chronic pre-treatment effects of PC DCM and EtOAc on ketamine enhanced immobility time in FST}

The protective chronic effects of the DCM and EtOAc fractions of PC against ketamine-induced negative symptoms of psychosis were studied, using the FST model. We observed that repeated ketamine treatment $(30 \mathrm{mg} / \mathrm{kg} /$ day, i.p. for 10 days) increased the immobility time, and significantly ( ${ }^{* *} \mathrm{P}<0.01$ ) persisted for 5 days after ketamine withdrawal. Pre-treatment with the DCM fraction of PC (500, 250, $125 \mathrm{mg} / \mathrm{kg}$, p.o. for 10 days) revealed significant protection against ketamine-induced immobility $\left({ }^{* * *} \mathrm{P}<0.001\right)$ on day 11 , which persisted up to the $15^{\text {th }}$ day ( $\left.{ }^{* *} \mathrm{P}<0.001\right)$ of the experiment. The EtOAc fraction also gave a dose-dependent significant [500 mg/kg, p.o. $\left({ }^{*} \mathrm{P}<0.05\right) ; 250$ \& $125 \mathrm{mg} / \mathrm{kg}$, p.o. $\left.\left({ }^{* *} \mathrm{P}<0.001\right)\right]$ decrease in all the three doses and persisted up to the $15^{\text {th }}$ day $\left({ }^{* *} \mathrm{P}<0.001\right)$ of the experiment. Furthermore, risperidone and haloperidol treatment for 10 days significantly $\left({ }^{* *} \mathrm{P}<0.001\right)$ reduced the duration of immobility on days 11 and 15, respectively, as against ketamine treated groups (Figure 3 a \& b).
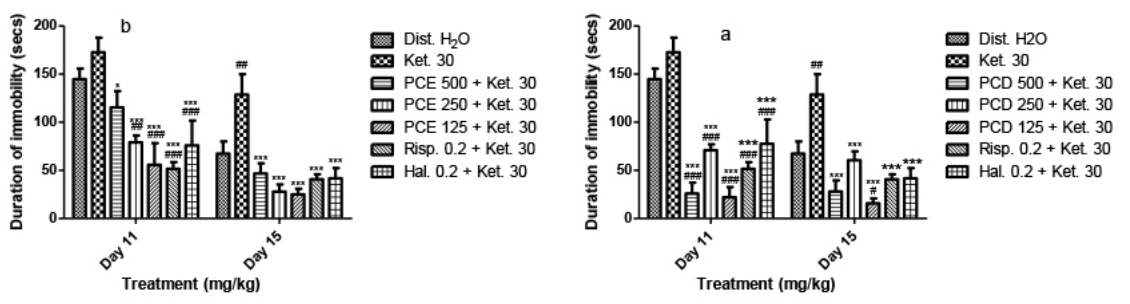

Figure 3. Effect of pre-treatment with DCM and EtOAc fractions of PC on ketamine-enhanced immobility in FST. Bar chart indicates day-dependent effect of the fractions, risperidone, and haloperidol against ketamine - enhanced immobility in mice. Data were mean \pm SEM $(n=6)$. ${ }^{*} \mathrm{P}<0.05,{ }^{* *} \mathrm{P}<0.001$, compared with negative control group and $\# \mathrm{P}<0.05$, \#\#P<0.01, $\# \# \# P<0.001$, compared with distilled water (two-way ANOVA showed significant difference between interaction, treatment groups and duration of immobility among the experimental days, followed by a Bonferroni multiple comparison post hoc test) 


\section{Effect of DCM and EtOAc fractions of PC on ketamine induced cognitive dysfunction in Y-maze Test}

Pre-treatment effect of PC fractions (DCM and EtOAc) on reversal of ketamineinduced cognitive dysfunction was evaluated by the number of arm entries and sequence of arm entry using Y-maze apparatus. Chronic treatment with ketamine (30 mg/kg, i.p.) induced memory impairment with a decrease in percentage correct alternation on days 1, 5 and 10, respectively as compared to the group that received distilled water only $(10 \mathrm{~mL} / \mathrm{kg})$. Pre-treatment with the DCM (day 5) and EtOAc fractions of PC (day 10) at $250 \mathrm{mg} / \mathrm{kg}$ p.o. $1 \mathrm{~h}$ before administration of ketamine, significantly ( $\left.{ }^{*} \mathrm{P}<0.05\right)$ reversed the ketamine effect by increasing the percentage correct alternation on experimental days. In addition, risperidone and haloperidol showed increase in percentage correct alternation as compared to ketamine treated groups (Figure $4 \mathrm{a}$ and $4 \mathrm{~b}$ ).
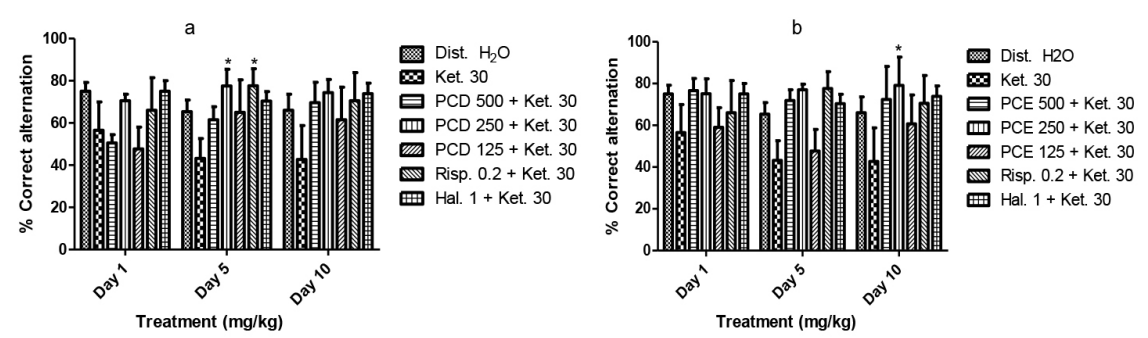

Figure 4. Effect of pre-treatment with dichloromethane and ethyl acetate fractions of PC on ketamine-induced cognitive dysfunction. Bar chart indicates day - dependent effect of the fractions, risperidone, and haloperidol against ketamine- enhanced immobility in mice. Data were mean \pm SEM $(n=6)$. ${ }^{*} P<0.05$, compared with negative control group (two-way ANOVA revealed significance difference between all treatment groups, followed by a Bonferroni multiple comparison post hoc test)

\section{Catalepsy}

The active fractions of PC (DCM and EtOAc) were tested for cataleptic effect at higher and lower doses of $500 \mathrm{mg} / \mathrm{kg}$ and $125 \mathrm{mg} / \mathrm{kg}$, respectively, singly and combined with haloperidol. It was observed that the group of animals treated with the DCM fraction at $500 \mathrm{mg} / \mathrm{kg}$ was not showing catalepsy up till $60 \mathrm{~min}$ after administration as compared to mice treated with $125 \mathrm{mg} / \mathrm{kg}$. Also, when combined with haloperidol, the DCM fraction $(500 \mathrm{mg} / \mathrm{kg}$ ) reduced the cataleptic effect induced by haloperidol (Table 2). Furthermore, the administration of the EtOAc fraction only, did not show catalepsy at both 500 and 125 (mg/ $\mathrm{kg}$ ) up till 120 min of administration, it also reduced the catalepsy caused by haloperidol. However, the $500 \mathrm{mg} / \mathrm{kg}$ dose was more effective (Table 3). The 
two active fractions of PC (DCM and EtOAc) did not induce catalepsy when administered singly and also reduced the cataleptic effect induced by haloperidol when it was coadministered with haloperidol. This implies that the DCM and EtOAc fractions of PC are good candidates of antipsychotics with little or no side effect.

Philenoptera cyanescens has been reported for various pharmacological properties $^{40,41}$. It has been traditionally used in Nigerian ethnomedicine for the treatment of mentally derailed people ${ }^{42}$. We previously reported the effect of the crude extract and fractions of this plant on amphetamine and apomorphine induced behavioural paradigms ${ }^{34,35}$, but in this study, the effect of the crude and fractions of PC against ketamine-induced psychosis was investigated. This is important because ketamine is known to affect dopaminergic, serotonergic and cholinergic receptors ${ }^{43}$, while apomorphine and amphetamine are stimulants of dopaminergic receptors ${ }^{44,45}$. Hence, the major goal of this study was to investigate the antipsychotic potential of Philenoptera cyanescens (PC) crude extract and fractions against ketamine-induced experimental psychosis models in mice.

Table 2. Effect of Haloperidol and DCM fraction of Philenoptera cyanescens on catalepsy

\begin{tabular}{|c|c|c|c|c|c|c|}
\hline \multirow{2}{*}{ Group } & \multirow{2}{*}{ Treatment } & \multicolumn{5}{|c|}{ Time $(\mathbf{m i n}) /$ Mean Catalepsy Score \pm SEM, $\mathrm{n}=6$} \\
\cline { 3 - 7 } & & $\mathbf{0} \mathbf{m i n}$ & $\mathbf{3 0} \mathbf{m i n}$ & $\mathbf{6 0} \mathbf{m i n}$ & $\mathbf{9 0} \mathbf{m i n}$ & $120 \mathrm{~min}$ \\
\hline 1 & Distilled water $10 \mathrm{~mL} / \mathrm{kg}$ & $3.50 \pm 0.85$ & $5.50 \pm 1.06$ & $10.0 \pm 4.14$ & $46.83 \pm 18.79$ & $58.83 \pm 19.28$ \\
\hline 2 & Haloperidol $1 \mathrm{mg} / \mathrm{kg}$ & $137.30 \pm 28.86$ & $224.00 \pm 30.19$ & $209.70 \pm 31.67$ & $249.50 \pm 18.99$ & $209.70 \pm 21.74$ \\
\hline 3 & PC DCM $500 \mathrm{mg} / \mathrm{kg}$ & $8.00 \pm 2.77$ & $3.33 \pm 0.62$ & $8.00 \pm 3.36$ & $28.83 \pm 20.16$ & $37.67 \pm 21.01$ \\
\hline 4 & PC DCM $125 \mathrm{mg} / \mathrm{kg}$ & $6.67 \pm 2.23$ & $22.33 \pm 12.09$ & $80.83 \pm 35.93$ & $49.17 \pm 23.33$ & $61.83 \pm 20.01$ \\
\hline 5 & Hal.+PC DCM $500 \mathrm{mg} / \mathrm{kg}$ & $32.50 \pm 26.52$ & $65.00 \pm 29.17$ & $105.70 \pm 39.92$ & $115.50 \pm 38.84$ & $97.33 \pm 39.40$ \\
\hline 6 & Hal.+PC DCM $125 \mathrm{mg} / \mathrm{kg}$ & $7.67 \pm 2.80$ & $109.3 \pm 39.03$ & $134.80 \pm 27.70$ & $156.30 \pm 29.27$ & $158.50 \pm 24.32$ \\
\hline
\end{tabular}

Table 3. Effect of Haloperidol and EtOAc fraction of Philenoptera cyanescens on catalepsy

\begin{tabular}{|c|c|c|c|c|c|c|}
\hline \multirow{2}{*}{ Group } & \multirow{2}{*}{ Treatment } & \multicolumn{5}{|c|}{ Time (min)/Mean Catalepsy Score \pm SEM, $\mathrm{n}=6$} \\
\cline { 3 - 7 } & & $\mathbf{0}$ min & $30 \mathrm{~min}$ & $\mathbf{6 0} \mathrm{min}$ & $\mathbf{9 0} \mathbf{m i n}$ & $120 \mathrm{~min}$ \\
\hline 1 & Distilled water $10 \mathrm{~mL} / \mathrm{kg}$ & $3.50 \pm 0.85$ & $5.50 \pm 1.06$ & $10.0 \pm 4.14$ & $46.83 \pm 18.79$ & $58.83 \pm 19.28$ \\
\hline 2 & Haloperidol $1 \mathrm{mg} / \mathrm{kg}$ & $137.30 \pm 28.86$ & $224.00 \pm 30.19$ & $209.70 \pm 31.67$ & $249.50 \pm 18.99$ & $209.70 \pm 21.74$ \\
\hline 3 & PC EtOAc $500 \mathrm{mg} / \mathrm{kg}$ & $1.00 \pm 0.00$ & $1.17 \pm 0.17$ & $1.50 \pm 0.34$ & $4.83 \pm 2.69$ & $2.33 \pm 0.62$ \\
\hline 4 & PC EtOAc $125 \mathrm{mg} / \mathrm{kg}$ & $1.33 \pm 0.21$ & $3.50 \pm 1.34$ & $3.83 \pm 1.20$ & $5.83 \pm 1.96$ & $6.17 \pm 2.02$ \\
\hline 5 & Hal. + PC EtOAc $500 \mathrm{mg} / \mathrm{kg}$ & $3.00 \pm 1.18$ & $23.67 \pm 7.99$ & $82.83 \pm 23.58$ & $148.80 \pm 35.06$ & $127.00 \pm 25.00$ \\
\hline 6 & Hal. + PC EtOAc $125 \mathrm{mg} / \mathrm{kg}$ & $2.33 \pm 0.80$ & $83.33 \pm 34.26$ & $155.50 \pm 34.07$ & $198.00 \pm 27.92$ & $218.20 \pm 21.91$ \\
\hline
\end{tabular}


Reports from literature revealed that ketamine, an antagonist of N-methyl-D aspartate (NMDA) receptor induces psychotic-like symptoms in healthy human beings ${ }^{45-47}$ and exacerbates psychosis in patients with schizophrenia ${ }^{48-51}$. Furthermore, animal and human cognitive functions are disrupted ${ }^{13}$, thereby producing schizophrenia like deficits ${ }^{52}$. Chatterjee et al. (2011a) tried to characterize a ketamine-induced model in mice, with certain symptoms observed in schizophrenia using selected behavioural phenotypes, especially stereotypy behaviour and locomotor activity, and they reported increase in the 3, 4-Dihydroxyphenylacetic acid/Dopamine (DOPAC/DA) ratio in the striatal areas of the brain both after short and long term use of ketamine administration. They also demonstrated that ketamine induced anxiety of various neurotransmitters level such as glutamate, glycine, noradrenalin and related receptor systems (dopaminergic, serotoninergic, and cholinergic systems), which are implicated in the pathophysiology of schizophrenia ${ }^{43}$.

In experimental animals, locomotion activity is mostly increased by CNS stimulants and reduced by CNS depressants7. Enhanced locomotor activity has been linked to the dopaminergic hyper activation in striatal areas of mouse brain $^{8}$. This inhibitory effect has been shown to increase activity of the neurons and cause excess release of dopamine in the limbic striatal regions. Acute ketamine treatment has been reported to cause $60 \%$ increase in dopamine level in the cortex of animal, and $130 \%$ increase in the striatal region of the brain ${ }^{43}$. Bacopa monniera was shown to regulate the dopamine pathway in the striatum of mice, suggesting its protective action against positive symptoms of psychosis ${ }^{36}$. In this study the locomotion deficits induced by ketamine were significantly reduced after being exposed to the crude extract and fractions of PC. The Hex $\left({ }^{* * *} \mathrm{P}<0.001\right)$, DCM $\left({ }^{* * *} \mathrm{P}<0.001\right)$, EtOAc $\left({ }^{* * *} \mathrm{P}<0.001\right)$ and $\mathrm{BuOH}\left(* * * \mathrm{P}<0.001,{ }^{*} \mathrm{P}<0.05\right)$ fractions significantly reduced the hyper-locomotion induced by ketamine. An average dose of $250 \mathrm{mg} / \mathrm{kg}$ was more effective and was found comparable to the standard drug, risperidone. This may be due to partial restoration of striatal dopamine levels ${ }^{43}$, thus, suggesting it may mediate its protective effect against the positive symptoms through regulation of the dopamine pathway in the striatum.

Ambulation in the animals supports the result of hyper-locomotion. When there was an increase in hyper-locomotion, the duration of ambulation was reduced. A significant difference was not observed between the negative control group and PC crude extract-treated mice at various doses (125, 250, and 500 $\mathrm{mg} / \mathrm{kg}$ ), in the time animals spent in ambulation (walking around). The hexane $\left({ }^{*} \mathrm{P}<0.05,{ }^{* * *} \mathrm{P}<0.001\right)$, DCM $\left({ }^{* *} \mathrm{P}<0.01,{ }^{* * *} \mathrm{P}<0.001\right)$ fractions at all 
doses $(125,250$, and $500 \mathrm{mg} / \mathrm{kg})$, were significantly different from the negative control group compared to the standard drugs, haloperidol $\left({ }^{* * *} \mathrm{P}<0.001\right)$ and risperidone $\left({ }^{* *} \mathrm{P}<0.001\right)$, indicating that there was a reduction in ambulation. Also, at $250 \mathrm{mg} / \mathrm{kg}$ and $500 \mathrm{mg} / \mathrm{kg}$, the EtOAc fraction $(* * \mathrm{P}<0.01)$ was significantly different from the control group. Likewise, $\mathrm{BuOH}\left({ }^{* *} \mathrm{P}<0.01\right)$ at $250 \mathrm{mg} / \mathrm{kg}$ differed significantly from control group, but the aqueous fraction showed no significant difference at all doses.

Stereotypy, one of the most prominent symptoms seen in people with mental disorder, is usually seen in the form of repetitive performance of a set of strange behaviours such as making the same kind of comments or asking the same questions $^{9,10}$. In experimental animals, stereotypy is usually observed as persistent sniffing, abnormal sideways movements of the head, intense licking, and chewing behaviours ${ }^{10}$. The acute administration of the crude extract and fractions of PC significantly suppressed the stereotypy behaviour induced by ketamine indicating its neuroleptic properties ${ }^{53}$. This investigation is in line with earlier research on the inhibition of ketamine-induced stereotypy by ethanol extract of Terminalia ivorensis ${ }^{14}$. Also, Amoateng et al. (2017) reported the antagonism of apomorphine-induced stereotypy by Synedrella nodiflora whole plant.

We minimized the use of animals in the behavioural studies by using the same animals for both hyper-locomotion and stereotype behaviour paradigm. The behavioural results showed that the PC fractions inhibited hyper-locomotion and stereotypy induced by ketamine (compared to risperidone) and might be due to its atypical mechanistic effects through the NMDA receptor ${ }^{54}$, which resulted into the modulation of dopamine, hence, its efficiency against positive symptoms of psychosis.

Chronic administration of ketamine has been reported to enhance immobility in forced swim test, and used as a model for negative symptoms of psychosis ${ }^{13}$, such as avolition (severe decrease in motivation to initiate and perform self-directed purposeful tasks). We observed that chronic administration of DCM and EtOAc fractions of PC gave a significant decrease in the duration of immobility. Twenty-four hours after treatment, all the three doses of DCM fraction significantly reduced the immobility time $\left({ }^{*} \mathrm{P}<0.05\right.$, $\left.{ }^{* *} \mathrm{P}<0.001\right)$, with $125 \mathrm{mg} / \mathrm{kg}$ being more active than the standard drugs (haloperidol and risperidone). This activity was also consistent at day 15 post treatment. The EtOAc fraction gave a dose-dependent decrease in the duration of immobility in the FST model at day 11, with $125 \mathrm{mg} / \mathrm{kg}$ being the most active and consistent on day 15 of the study. The efficiency of antipsychotics such as clozapine, risperidone in negative symptoms of psychosis has been credited to its serotonin (5HT-2) receptor 
blockage, Chatterjee et al. (2012) have reported that chronic administration of ketamine induces an increase in the serotonin content in brain cortex, and that pre-treatment of animals with Bacopa monniera normalised the serotonergic receptor, thereby protecting the animals against negative symptoms of psychosis $^{36}$. This is in support of our study whereby the DCM and EtOAc fractions of PC gave protective effect against ketamine-enhanced immobility in negative symptoms of psychosis.

Cognitive dysfunction such as attention deficits, short- and long-term working memory are symptoms seen in psychotic patients ${ }^{11}$. Learning and memory are mostly severe in patients ${ }^{55}$ and are known to be a major factor in determining the level of disabled patients with psychotic experience in personal living, social and occupational functions ${ }^{56}$.

The Y-maze test has previously been used to investigate the effectiveness of antipsychotic drugs on memory and learning function in rodents ${ }^{12}$. It involves measuring the spatial working memory, which is based on rodent's willingness to explore new environments. Rodents prefer to explore new arm of the maze, rather than return to a previously visited arm. It is mostly used to measure the cognitive deficiencies in transgenic mice and investigate effects of novel principles on cognition. In this study, we also observe the memory dysfunction properties of ketamine, which was restored by the DCM and EtOAc fractions of PC. The DCM fraction at $250 \mathrm{mg} / \mathrm{kg}$ consistently gave high percentage correct alternation of $70.5 \%, 77.5 \%$ and $74.3 \%$ on days 1,5 and 10 , respectively. Also, the EtOAc $(250 \mathrm{mg} / \mathrm{kg}$ ) gave $75.2 \%, 77.0 \%$, and $79.2 \%$ percentage correct alternation on days 1, 5 and 10, respectively. These results are comparable to the standards, risperidone (day $1-66 \%$, day $5-77.7 \%$, day $10-70.5 \%$ ) and haloperidol (day $1-75.0 \%$, day $5-70.3 \%$, day $10-73.8 \%$ ). Chatterjee et al., (2012), had reported that ketamine-disrupted memory has been linked to the abnormal functioning of the acetylcholine and glutamate neurotransmitters. Acetylcholine plays an important synaptic role in the initial stages of memory formation ${ }^{57}$, while glutamate mediates long-term potentiation and memory formation through the NMDA receptors. These two neurotransmitters were inhibited due to the administration of ketamine by enhancing the cholinesterase levels which is an enzyme that metabolizes acetylcholine, thus reducing its synaptic level. Our observation showed that PC DCM and EtOAc may mediate their protective effect against ketamine by antagonizing the cholinesterase activity and restoring glutamate levels in the brain.

Catalepsy has been used to predict safe tranquillizing activity and also to access motor effects of drugs, especially effects related to extrapyramidal symptoms 
(EPS ${ }^{14}$. It is one of the major side effects related to the use of orthodox antipsychotic drugs ${ }^{15}$. The EPS has been linked to the decrease of striatal dopamine D1 and D2 receptors ${ }^{16,17}$. Also, some other neurotransmitters such as serotonin, acetylcholine, opiods or adenosine have been implicated ${ }^{5}$. Therefore, testing for cataleptic behaviour in experimental animals forms an integral part of the discovery and development of antipsychotic drugs. The active fractions from the hyper-locomotion and stereotypy studies (DCM and EtOAc) were tested for catalepsy. Apparently, the absence of cataleptic effect in the DCM fractions of $\mathrm{PC}$ at $500 \mathrm{mg} / \mathrm{kg}$ (up till $120 \mathrm{~min}$ ) and the ability to reduce the catalepsy induced by haloperidol suggest that the extract at higher doses may not produce any significant motor side-effects. Also, the EtOAc fraction exhibited no cataleptic effect at both 500 and $125 \mathrm{mg} / \mathrm{kg}$ suggesting that this fraction does not possess any significant motor side effects at both lower and higher doses. These doses were also able to reduce haloperidol-induced catalepsy. This is in support of a previously reported study in which black tea extract effectively reduced haloperidol-induced catalepsy ${ }^{5}$. The appearance of cataleptic event in naïve mice at $60 \mathrm{~min}$ post-DCM fraction $(125 \mathrm{mg} / \mathrm{kg})$ administration and its significant increase in haloperidol-induced catalepsy also at the $30^{\text {th }} \mathrm{min}$ may suggest that motor side effects are likely to develop with lower doses of the extract ${ }^{38}$. The DCM and EtOAc fractions having shown a protective effect against ketamine-induced positive symptoms, without any extrapyramidal side effects, could possess enormous antipsychotic potential. The DCM fraction of Philenoptera cyanescens was not reported earlier, it shows good activity alongside the ethyl acetate fraction, which also potentiated antipsychotic activities when compared to reference antipsychotic drugs; haloperidol and risperidone, suggesting that it may contain typical and/atypical compound(s) responsible for inhibiting psychosis.

These findings provide supportive evidence demonstrating that methanol crude extract and fractions of Philenoptera cyanescens leaves possess safe antipsychotic properties with no extrapyramidal effects when tested in ketamine-induced positive, negative symptoms as well as cognitive impairments, and catalepsy models of psychosis. This efficacy may be due to its dopaminergic, serotonergic and cholinergic neurotransmission normalisation effects. The DCM fraction has not been reported earlier. The isolation, purification and identification of the bioactive constituents of Philenoptera cyanescens is on-going, as it may lead to the discovery of new molecular entities for future development of antipsychotic drugs, which could serve as an alternative safe therapy for treating psychosis in humans. 


\section{AUTHORS' CONTRIBUTION}

Author MAS took part in research concept and design, supervision, analysis, interpretation of the result findings, writing of manuscript, ITA carried out the laboratory work, analysed, interpreted the findings from the results and wrote the draft manuscript, KR was the host supervisor in whose lab the research was carried out and also supervised the study. All authors have read and approved the manuscript.

\section{ACKNOWLEDGEMENT}

The authors acknowledge the Department of Pharmacognosy, University of Ibadan, for giving the opportunity to carry out part of the research abroad. Also, Department of Pharmacy, Neuropharmacology unit, Natural Product Research lab and COMSATS Institute of Information Technology, Abbottabad, Pakistan are gratefully acknowledged for laboratory space.

Funding: This study enjoyed financial support from the Tertiary Education Trust Fund (TETFund) grant awarded through the University of Ibadan to MAS. The authors are also grateful to The World Academy of Science (TWASCIIT) Fellowship award with reference no: 3240287155 for granting a fellowship to carry out part of this research. 


\section{REFERENCES}

1. World Health Organization. Investing in Mental Health, 2003.

2. Kumari, R.; Chatterjee, M.; Singh, S.; Kaundal, M.; Ashwalayan, V. D. Oxidative stress: A novel treatment target in psychiatric disorder. Int. J. Pharm. Sci. Rev. Res. 2011, 9, 165-72.

3. Reus, V. I. Mental disorders. In Harrison's principles of internal medicine. Fauci, A. S.; Braunwald, E.; Kasper, D. L. eds.; McGraw-Hill: New York, 20o8; pp 2710-23.

4. Meltzer, H. Antipsychotic agents \& lithium. In Basic \& Clinical Pharmacology; Katzung, B. G.; Masters, S. B.; Trevor, A. J. eds.; McGraw-Hill Companies: New York, 2010; pp 487-507.

5. Meyer, J. M. Pharmacotherapy of psychosis and mania. In the Pharmacological Basis of Therapeutics Goodman, L. S.; Gilman, A. G.; Brunton, L.; Chabner, B.; Knollman, B., Eds.; McGraw-Hill: New York, 2011; pp 417-55.

6. Trivedi, M. S.; Jarbe, T. A. Brief review on recent developments in animal models of schizophrenia. Indian J. Pharmacol. 2011, 43, 375-80.

7. Nesa, L.; Munira, S.; Mollika, S.; Islam, M.; Choin, H.; Chouduri, A. U.; Naher, N. Evaluation of analgesic, anti-inflammatory and CNS depressant activities of methanolic extract of Lawsonia inermis barks in mice. Avicenna J. Phytomed. 2014, 4, 287-96.

8. Irifune, M.; Shimizu, T.; Nomoto, M. Ketamine-induced hyperlocomotion associated with alteration of presynaptic components of dopamine neurons in the nucleus accumbens of mice. Pharmacol. Biochem. Behav. 1991, 40, 399-407.

9. Davis, K. L.; Kahn, R. S.; Grant, K. O.; Davidson, M. Dopamine in schizophrenia: a review and reconceptualization. Am. J. Psychiatry 1991, 148, 1474-6.

10. Morrens, M.; Hulstijn, W.; Lewi, P. J.; De Hert, M.; Sabbe, B. G. Stereotypy in schizophrenia. Schizophrenia Res. 2006, 84, 397-404.

11. Harvey, P. D.; Green, M. F.; Keefe, R. S.; Velligan, D. I. Cognitive functioning in schizophrenia: A consensus statement on its role in the definition and evaluation of effective treatments for the illness. J. Clin. Psychiatry. 2004, 65, 361-72.

12. Monte, A. S.; Greicy, C. S.; Roger, S. M.; Joanna, K. S.; Júnia, V. S.; Rafaela, C. C.; Bruna, M. M.; Ribeiro, D. F.; Silvânia, M. M. Prevention and reversal of ketamine-induced schizophrenia related behavior by minocycline in mice: Possible involvement of antioxidant and nitrergic pathway. J. Psychopharmacol. 2013, 11, 1032-1043.

13. Chatterjee, M.; Ganguly, S.; Srivastava, M.; Palit, G. Effect of 'chronic' versus 'acute' ketamine administration and its 'withdrawal' effect on behavioural alterations in mice: Implications for experimental psychosis. Behav. Brain Res. 2011a, 216, 247-254.

14. Ben-Azu, B.; Aderibigbe, A. O.; Adeoluwa, O. A.; Iwalewa, E. O. Ethanol Extracts of Terminalia ivorensis (Chev A.) Stem Bark Attenuates the Positive, Negative and Cognitive Symptoms of Psychosis in Experimental Animal Models. British J. Pharm. Res. 2016, 12, 1-14.

15. Sanberg, P. R.; Bunsey, M. D.; Giordano, M.; Norman, A. B. The catalepsy test: its ups and downs. Behav. Neurosci. 1988, 102, 748.

16. Shopsin, B.; Klein, H.; Aaronsom, M.; Collora, M. Clozapine, chlorpromazine, and placebo in newly hospitalized, acutely schizophrenic patients: a controlled, double-blind comparison. Arch. Gen. Psychiatry. 1979, 36, 657-664.

17. Sanberg, P. R. Haloperidol-induced catalepsy is mediated by postsynaptic dopamine receptors. Nature. 1980, 284, 472-473. 
18. Zhang, Z. J. Therapeutic effects of herbal extracts and constituents in animal models of psychiatric disorders. Life Sci. 2004, 75, 1659-1699.

19. Dailligna, O. P.; Fett, P.; Gomes, M. W. Caffeine and adenosine A (2a) receptor antagonists prevent beta-amyloid (25-35)-induced cognitive deficits in mice. Exp. Neurol. 2007, 203, 241-245.

20. Chatterjee, M.; Verma, P.; Maurya, R.; Palit, G. Evaluation of ethanol leaf extract of Ocimum sanctum in experimental models of anxiety and depression. Pharm. Biol. 2011b, 49, 477-483.

21. Ishola, I. O.; Chatterjee, M.; Tota, S. K.; Tadigopulla, N.; Adeyemi, O. O.; Palit, G.; Shukia, R. Antidepressant and anxiolytic effects of amentoflavone isolated from Cnestis ferruginea in mice. Pharmacol. Biochem. Behav. 2012, 103, 322-331.

22. Chatterjee, M.; Verma, R.; Lakshmi, V.; Sengupta, S.; Kumar, A. V.; Mandir, A. A.; Palit, G. Anxiolytic effects of Plumeria rubra var. acutifolia (Poiret) L. flower extracts in the elevated plus-maze model of anxiety in mice. Asian J. Psychiatry. 2013, 6, 113-18.

23. Kumar, V.; Jaiswal, A. K.; Singh, P. N.; Bhattacharya, S. K. Anxiolytic activity of Indian Hypericum perforatum Linn: an experimental study. Indian J. Exp. Biol. 2oooa, 38, 36-41.

24. Kumar, V.; Singh, P. N.; Muruganandam, A, V.; Bhattacharya, S. K. Effect of Indian Hypericum perforatum Linn on animal models of cognitive dysfunction. J. Ethnophamacol. 20oob, 72, 119-128.

25. Khalifa, A. E. Hypericum perforatum as a nootropic drug: enhancement of retrieval memory of a passive avoidance conditioning paradigm in mice. J. Ethnophamacol. 2oo1, $76,49-57$.

26. Klusa, V.; Germane, S.; Noldner, M.; Chatterjee, S. Hypericum extract and hyperforin: memory-enhancing properties in rodents. Pharmacopsychiatry. 2001, 34, S61-S69.

27. Kumar, V.; Khanna, V. K.; Seth, P. K.; Singh, P. N.; Bhattacharya, S. K. Brain neurotransmitter receptor binding and nootropic studies on Indian Hypericum perforatum Linn. Phytother. Res. 2002, 16, 210-216.

28. Shaheen, H. M.; Ali, B. H.; Alqarawi, A. A.; Bashir, A. K. Effect of Psidium guajava leaves on some aspects of the central nervous system in mice. Phytother. Res. 2ooo, 14, 107-111.

29. Amos, S.; Binda, L.; Vongtau, H.; Chindo, B.; Abbah, J.; Sambo, N.; Odin, E. M.; Okwute, S. K.; Akah, P.; Wambebe, C.; Gamaniel, K. Sedative effects of the methanolic leaf extract of Newbouldia laevis in mice and rats. Boll. Chim. Farm. 2002, 141, 471-475.

30. Das, A.; Shanker, G.; Nath, C.; Pal, R.; Singh, S.; Singh, H. K. A comparative study in rodents of standardized extracts of Bacopa monniera and Ginkgo biloba: Anticholinesterase and cognitive enhancing activities. Pharmacol. Biochem. Behav. 2002, 73, 893-900.

31. Rai, D.; Bhatia, G.; Palit, G.; Pal, R.; Singh, S.; Singh, H. K. Adaptogenic effect of Bacopa monniera (Brahmi). Pharmacol. Biochem. Behav. 2003, 75, 823-830.

32. Chatterjee, M.; Verma, P.; Palit, G. Comparative evaluation of Bacopa monniera and Panax quniquefolium in experimental anxiety and depressive models in mice. Indian J. Exp. Biol. 2010, 48, 306-313.

33. Amoateng, P.; Adjei, S.; Osei-safo, D.; Kukuia, K. K. E.; Bekoe, E. O. Extract of Synedrella nodiflora (L) Gaertn exhibits antipsychotic properties in murine models of psychosis. BMC Complement. Altern. Med. 2017, 17, 389-402.

34. Sonibare, M. A.; Umukoro, S.; Shonibare, E. T. Antipsychotic property of aqueous and 
ethanolic extract of Lonchocarpus cyanescens (Schumach and Thonn.) Benth. (Fabaceae) in rodents. J. Nat. Med. 2012, 66, 127-132.

35. Arowona, I. T.; Sonibare, M. A.; Umukoro, S. Antipsychotic property of solvent-partitioned fractions of Lonchocarpus cyanescens leaf extract in mice. J. Basic Clin. Physiol. Pharmacol. 2014, 25, 235-240.

36. Chatterjee, M.; Verma, R.; Kumari, R.; Singh, S.; Kumar, A. D.; Palit G. Antipsychotic activity of standardized Bacopa extract against ketamine-induced experimental psychosis in mice: Evidence for the involvement of dopaminergic, serotonergic, and cholinergic systems. Pharm. Biol. 2015, 53, 1850-1860.

37. Bourin, M.; Poisson, L.; Larousse, C. Piracetam interaction with neuroleptics in psychopharmacological tests. Neuropsychobiology. 1986, 19, 93-96.

38. Nayebi, A. M.; Rad, S. R.; Saberian, M.; Azimzadeh, S.; Samini, M. Buspirone improves 6-hydroxydopamine-induced catalepsy through stimulation of nigral 5-HT (1A) receptors in rats. Pharmacol. Res. 2010, 62, 258-264.

39. Pemminati, S.; Nair, V.; Dorababu, P.; Gopalakrishna, H. N.; Pai, M. Effect of ethanolic leaf extract of Ocimum sanctum on haloperidol-induced catalepsy in albino mice. Indian $J$. Pharmacol. 2007, 39, 87-89.

40. Ndukwe, K. C.; Lamikanra, A.; Okeke, I. N. Antibacterial Activity of Plants used as chewing sticks in Africa. Drug Future. 2004, 29, 1221.

41. Moronkola, D. O.; Adedeji, A. A.; Oyewole, I. O.; Ogunwande, I. A.; Oladosu, I. A. "Survey and Accounts of Anti-Malaria Ethnomedicinal herbs used in South-Western Nigeria and vector repellant activities of their volatile oils," The African Network for Drugs and Diagnostics [ANDI], 2nd Stakeholders Meeting \& Conference, Medical Research Council [MRC], Cape Town, 2009.

42. Sonibare, M. A.; Soladoye, M. O.; Subuloye, T. O. Ethnobotanical survey of anti-psychotic plants in Lagos and Ogun States of Nigeria. Eur. J Sci. Res. 2008, 19, 634-43.

43. Chatterjee, M.; Verma, R.; Ganguly, S.; Palit, G. Neurochemical and molecular characterization of ketamine-induced experimental psychosis model in mice. Neuropharmacology. 2012, 63, 983-991.

44. Stolk, J. M.; Rech, R. H. Antagonism of O-amphetamine by methyltyrosin. Behavioural evidence for participation of cathelcolamine stores and synthesis in the amphetamine stimulant response. Neuropharmacology. 1970, 9, 249-263.

45. Swerdlow, N. R.; Braff, D. L.; Taaid, N.; Geyer, M. A. Assessing the validity of an animal model of deficient sensorimotor gating in schizophrenic patients. Arch. Gen. Psychiatry. 1994, 51, 139-154.

46. Bakker, C. B.; Amini, F. B. Observations on the psychotomimetic effects of Sernyl. Compr. Psychiatry. 1961, 2, 269-280.

47. Allen, R. M.; Young, S. J. Phencyclidine-induced psychosis. Am. J. Psychiatry. 1978, 135, 1081-1084

48. Adler, C. M.; Malhotra, A. K.; Elman, I. Goldberg, T.; Egan M.; Pickar, D.; Breier, A. Comparison of ketamine-induced thought disorder in healthy volunteers and thought disorder in schizophrenia. Am. J. Psychiatry. 1999, 156, 1646-1649

49. Lahti, A. C.; Koffel, B.; LaPorte, D.; Tamminga, C. A. Sub anesthetic doses of ketamine stimulate psychosis in schizophrenia. Neuropsychopharmacology 1995, 13, 9-19.

50. Malhotra, A. K.; Pinals, D. A.; Adler, C. M, et al. Ketamine-induced exacerbation of psy- 
chotic symptoms and cognitive impairment in neuroleptic-free schizophrenics. Neuropsychopharmacology. 1997, 17, 141-150.

51. Lahti, A. C.; Martin, M.D.; Weiler, M. A.; Tamara Michaelidis, B. A.; Parwan, M.A.; Carol, D. A.; Tamminga, M.D. Effects of ketamine in normal and schizophrenic volunteers. Neuropsychopharmacology. 2001, 25, 455-467.

52. Jentsch, J. D.; Roth, R. H. The neuropsychopharmacology of phencyclidine: From NMDA receptor hypofunction to the dopamine hypothesis of schizophrenia. Neuropsychopharmacology. 1999, 20, 201-225.

53. Waddington, J. L.; Gamble, S. J. Neuroleptic treatment for a substantial proportion of adult life: behavioural sequelae of 9 months haloperidol administration. Eur. $J$ Pharmacol. 1980, 67,363 .

54. Leite, J. V.; Guimara es, F. S.; Moreira, F. A. Aripiprazole, an atypical antipsychotic, prevents the motor hyperactivity induced by psychotomimetics and psychostimulants in mice. Eur. J. Pharmacol. 2008, 578, 222- 227.

55. Saykin, A. J.; Gur, R. C.; Gur, R. E.; et al. Neuropsychological function in schizophrenia. Selective impairment in memory and learning. Arch. Gen. Psychiatry. 1991, 48, 618-624.

56. Green, M. F.; Kern. R. S.; Braff, D. L.; Mintz, J. Neurocognitive deficits and functional outcome in schizophrenia: Are we measuring the "right stuff"? Schizophr. Bull. 20oo, 26, 119-136.

57. Hasselmo, M. E. The role of acetyPCholine in learning and memory. Curr. Opin. Neurobiol. 2006, 16, 710-715.

58. Porsolt, R. D. Moser, P. G.; Castagné, V. Behavioral indices in antipsychotic drug discovery. J. Pharmacol. Exp. Ther. 2010, 333, 632-638. 